\section{Marx, Weber e a modernidade: capitulos de um (des)encontro histórico}

Michael Löwy. La cage d'acier: Max Weber et le marxisme wébérien. Paris, Stock, 2013. 198 páginas.

\section{Fabio Mascaro Querido}

A um só tempo marxista militante e weberiano erudito, Michael Löwy se engajou nas últimas décadas em uma tentativa de integrar à teoria social fundada por Marx aspectos importantes do diagnóstico crítico de Max Weber sobre a modernidade. A partir de uma leitura inovadora e heterodoxa da obra do sociólogo de Heidelberg, Löwy retoma em La cage d'acier: Max Weber et le marxisme wébérien - uma corrente subterrânea do marxismo ocidental, o "marxismo weberiano" (assim designado por Merleau-Ponty), cuja crítica da racionalidade instrumental e das "águas glaciais do cálculo egoísta" (Marx) é hoje, na sua opinião, ainda mais atual, em face da configuração contemporânea do sistema capitalista.

Como se pode ver no primeiro dos seis capítulos do livro, Michael Löwy não minimiza as diferenças (e tampouco os antagonismos) metodológicas e, sobretudo, políticas entre Marx e Weber, diferenças amplamente ressaltadas pela literatura especializada. Enquanto Marx analisa "a origem do capitalismo moderno através do conceito de 'acumulação primitiva do capital'” (p. 18, tradução do autor da resenha), destacando o papel central dos fatores extraeconômicos, tais como a expropriação violenta dos camponeses, o tráfico de escravos e a pilhagem brutal das colônias, Weber sustenta, em revanche, em $A$ ética protestante e o espirito do capitalismo ([1904-1905] 2004), a hipótese segundo a qual o desenvolvimento do capitalismo, desde o século XVII, é o resultado da ética do trabalho, do esforço e da poupança ascética de alguns capitalistas, impulsionados pelo puritanismo calvinista - uma explicação, aliás, compatível com o discurso de autolegitimação dos proprietários de capital.

Todavia, do ponto de vista metodológico, quanto à relação entre fato religioso (notadamente o protestantismo) e capitalismo, as divergências entre os dois pensadores são mais nuançadas do que frequentemente se revela nas análises dos especialistas do século XX. À luz de uma leitura dialeticamente refinada de Marx, Michael Löwy defende a ideia de que, para o autor alemão, a religião não é um simples "reflexo" das condiçôes materiais, ao passo que Weber, por seu turno, reconhece a influência das condiçóes econômicas e sociais sobre a ascese protestante. No limite, para Löwy - à diferença das interpretaçóes marxistas simplistas de Weber -, a despeito de "certas passagens que se apresentam explicitamente [...] como uma refutação ao materialismo histórico, opondo-lhe uma relação causal 'espiritualista'” (p. 26), a obra célebre (A ética protestante...) do sociólogo alemão não sustenta nem o primado do fator econômico ("material"), nem do fator religioso ("espiritual"). Trata-se, segundo Löwy, acima de tudo, de um estudo profundo da relaçáo recíproca "entre essas duas estruturas culturais [...], que pouco se preocupa com a questão do primado” (p. 28). Michael Löwy apoia-se, aqui, parcialmente, em História e consciência de classe ([1923] 2012), obra de juventude de Georg Lukács, para quem a apreciação dos fatos revelados no estudo de Weber independe da aprovação ou não de sua interpretação causal.

É a partir dessa perspectiva que Michael Löwy logra destacar as afinidades e as "complementaridades" entre os dois pensadores alemães, em torno de uma análise comum do capitalismo que integra o papel das classes sociais e do Estado na formação de um sistema no qual os indivíduos encontram-se dominados por abstraçóes e relaçóes pessoais e "coisificadas". Assim, em vez de reafirmar uma vez mais o "abismo" epistemológico (para não dizer "ontológico") entre os dois autores, Löwy os integra através de suas críticas ao capitalismo moderno, privilegiando, na interpretação de Weber, "seu pessimismo cultural, seu diagnóstico implacável da civilização capitalista burocrática - 'dura como aço' e sua obscura premonição do futuro que ela nos prepara" (p. 9).

No segundo capítulo, Michael Löwy demonstra como este "pessimismo cultural" possibilitou ao sociólogo alemão o desenvolvimento de uma percepção (resignada, é bem verdade) das contradiçóes, dos paradoxos e dos limites da racionalidade moderna e do seu caráter formal/instrumental, e, 
tão importante quanto, da sua tendência a produzir efeitos que conduzem à reversão das aspiraçóes emancipadoras da modernidade. Esse diagnóstico crítico da civilização moderna aparece de forma notável nas últimas páginas d'A ética protestante..., nas quais Max Weber - abandonando momentaneamente sua reivindicação da ciência "livre de julgamentos de valor" - efetua uma espécie de "digressão crítica” (nas palavras de Löwy) sobre o tema da "petrificação mecanizada" característica do capitalismo consolidado. Para o sociólogo franco-brasileiro, nessas páginas notáveis, "felizmente Weber não conseguiu 'neutralizar' suas opiniôes e crenças"; bem ao contrário, ele deu livre curso "à uma visão radicalmente crítica e bastante pessimista do presente e do futuro da civilizaçáo moderna", de tal modo que elas "contrastam fortemente com o resto do texto, por seu caráter pessoal e axiologicamente engajado" (p. 58).

É nessas mesmas páginas citadas por Löwy que Weber elabora a conhecida alegoria da "gaiola de aço" (segundo a inexata tradução popularizada por Talcott Parsons), ou do "habitáculo duro como aço" (conforme prefere Löwy). Trata-se, para Löwy, não tanto de uma previsão das prováveis consequências futuras do processo de burocratizaçáo, e sim de uma alegoria da civilização capitalista industrial no presente, uma alegoria no sentido benjaminiano, na qual - tal como se pode ver no livro Origem do drama barroco alemão - "a facies hippocratica da história [...] se apresenta para o espectador como uma paisagem primitiva petrificada" (Benjamin, [1925] 2011, p. 180). Em outras palavras: a "gaiola de aço" weberiana constitui uma espécie de "iluminação profana", conforme a expressão do mesmo Benjamin em seu ensaio sobre os surrealistas (" $\mathrm{O}$ surrealismo - $\mathrm{O}$ último instantâneo da inteligência europeia", [1929] 1994), através da qual Max Weber denuncia - à sua maneira - o capitalismo como um "destino trágico", "sem porta de saída", em que toda a humanidade encontra-se aprisionada. Para esse "liberal atípico" que foi Weber, essa "gaiola" significa, como afirma Löwy, a perda de um valor que lhe era caro: a liberdade individual (p.72).

O conceito de "afinidades eletivas" - analisado por Michael Löwy no terceiro capítulo - revela, em Weber, uma tentativa de superar a abordagem tradicional da causalidade, e, assim, de "contornar o debate sobre o primado do 'material' ou do 'espiritual'” (p. 80). É por isso que tal conceito (transplantado por Goethe da alquimia para o terreno social da espiritualidade humana) ocupa um papel central em $A$ ética protestante..., malgrado o fato de ele ser mencionado apenas três vezes. $\mathrm{Na}$ ótica de Löwy, não surpreende que o termo náo tenha sido bem compreendido pela recepção anglo-saxônica e neopositivista de Weber: na tradução de Talcott Parsons (1930), por exemplo, a noção de afinidade eletiva é substituída por "certas correlações", o que, para o sociólogo franco-brasileiro, é muito diferente da ideia weberiana original de uma relação interna complexa e significativa entre duas configuraçôes socioculturais.

Esse conceito - ainda pouco estudado pelos especialistas em Weber - permite compreender, na perspectiva defendida por Michael Löwy, "um certo tipo de conjunção entre fenômenos aparentemente díspares" (p. 96), cuja dinamizaçāo depende sempre de condiçóes históricas e sociais concretas. Por essas razóes, o conceito de afinidades eletivas constitui, para Löwy, um ponto de partida para uma "nova abordagem" no campo da sociologia da cultura, ainda pouco explorada. O próprio Löwy, aliás, se utiliza amplamente dessa noçấo em seu livro, publicado na França em 1988, Redenção e utopia (1989), estudo sobre a cultura judaica na Europa central, no qual ele busca mostrar as afinidades eletivas entre messianismo libertário e romantismo anticapitalista, tal como elas aparecem na obra de diversos intelectuais judeus do início do século XX. Assim, o conceito de afinidade eletiva possibilita ao próprio Löwy esboçar uma concepção original da causalidade, em oposiçáo ao materialismo determinista dos epígonos marxistas.

No quarto capítulo, explorando as hipóteses weberianas, Löwy se propõe - de forma inovadora, se nâo ambiciosa - a reconstituir o "capítulo ausente [da] sociologia das religióes [de Weber], que se poderia intitular 'A ética católica e o espírito do capitalismo"' (p. 99). Através de algumas sugestōes de Weber a este respeito, Michael Löwy desenvolve um "subtexto", quer dizer, um "contra-argumento" apenas insinuado pelo sociólogo alemão em $A$ ética protestante... e em alguns outros textos menores, a 
saber: ao contrário do protestantismo, a ética católica - a despeito do papel da Igreja enquanto instituição e dos seus compromissos com a sociedade burguesa consolidada - "é pouco favorável ao espírito do capitalismo". Existiria, assim, segundo Löwy, entre o universo reificado, impessoal e "a-ético" do capitalismo e a ética católica uma espécie de "antipatia cultural", ou seja, uma "afinidade negativa". Isso explicaria a emergência, no século XX, de uma "tradição anticapitalista católica", sobretudo na América Latina, cuja expressão mais célebre foi a teologia da libertação - que não constitui, porém, como o próprio Löwy tentou demonstrar em seu livro de 1996 intitulado A guerra dos deuses (2000), um simples prolongamento do anticapitalismo tradicional da Igreja ou de sua versão francesa, mas sim a criação "de uma nova cultura religiosa", exprimindo as condiçôes específicas da região: "capitalismo dependente, pobreza massiva, violência institucionalizada [e] religiosidade popular" (p. 122).

$\mathrm{Na}$ terceira - e talvez mais interessante - parte do livro, que contém os dois últimos capítulos (quinto e sexto), Michael Löwy revela como o desenvolvimento inelutável do capitalismo industrial na Alemanha das primeiras décadas do século XX provocou - entre os intelectuais - o surgimento de uma atmosfera de desconfiança quase generalizada em relação à modernidade. É nesse contexto - estudado em detalhe pelo sociólogo franco-brasileiro na sua segunda tese de doutorado sobre "a evolução política do jovem Lukács" - que emerge o pessimismo weberiano, e a partir do qual se desenvolverá, mais tarde, "na República de Weimar, uma constelação intelectual, essencialmente composta de autores judeus de cultura alemá, que produzirá um conjunto de leituras anticapitalistas - assim como, em larga medida, antiprotestantes ou anticalvinistas do autor de A ética protestante" (p. 127). É o caso, por exemplo, de pensadores como Ernst Bloch, Walter Benjamin e Erich Fromm. Para Löwy, no quinto capítulo, as interpretações de Weber realizadas por esses autores constituem, antes de tudo, um "détournement", uma vez que eles utilizam os "argumentos ambivalentes de Weber para efetuar uma crítica, de inspiração socialista/romântica, contra a religião capitalista" (p. 127).
Praticamente no mesmo momento histórico, tal como Löwy demonstra no sexto e último capítulo do livro, com a obra mais importante do jovem Lukács, a já citada História e consciência de classe, surgiria efetivamente o que ele denomina - retomando o termo inventado por Merleau-Ponty "marxismo weberiano", que ganharia um novo fôlego com os primeiros representantes da Escola de Frankfurt (Adorno, Horkheimer e, de um certo modo, Marcuse). Mais do que em Bloch, Benjamin ou Fromm, certos temas e categorias da obra do sociólogo de Heidelberg ocupam um lugar estratégico no âmbito do "marxismo-weberiano" de Lukács, Adorno e/ou Horkheimer. Em Lukács, sobretudo no capítulo sobre a reificaçáo de História e consciência de classe - que, na opiniáo de Löwy, constitui uma "síntese" original da teoria do fetichismo da mercadoria de Marx e da teoria da racionalização de Weber -, encontra-se a primeira tentativa, a partir de um marxismo "antieconomicista" e "antipositivista", de "tomar Max Weber a sério e de se inspirar em suas ideias de modo significativo" (p. 152). Nas reflexōes de Adorno e Horkheimer, por sua vez, o diagnóstico "pessimista" esboçado em Dialética do esclarecimento ([1944] 1985) é amplamente inspirado em Weber, ainda que o nome do sociólogo alemão não apareça diretamente, e que o ponto de vista dos filósofos de Frankfurt - fundado na busca de um racionalismo concreto, "substancial", capaz de opor ao primado da racionalidade instrumental - seja mais "radical" que aquele revelado pelo "neokantismo resignado" de Weber (p. 163).

Dessa perspectiva, a obra de Jürgen Habermas principal "herdeiro" da primeira Escola de Frankfurt - representa, na ótica de Michael Löwy, uma "saída do marxismo-weberiano". Notadamente em sua obra magna, A teoria da açáo comunicativa, de 1981 (na ediçâao brasileira, Teoria do agir comunicativo, 2012), ele se afasta "consideravelmente" dessa tradição, propondo - através do conceito de "racionalidade comunicativa" - uma reconciliação com as normas da modernidade "realmente existente" (p. 180). Assim, dissociando-se do pessimismo weberiano, bem como da crítica marxista do capitalismo, Habermas aspira, segundo Löwy, a uma reativação da utopia burguesa da razão e do "projeto inacabado da modernidade", em oposição 
à "constataçáo brutal de Weber sobre a contradição inelutável dos valores e sua análise dos resultados alienantes da racionalidade instrumental" (p. 188).

Ora, como se pode ver, mais do que reafirmar a importância e a vitalidade do pensamento desses autores, Michael Löwy constitui, ele mesmo, um representante contemporâneo de tal "tradiçăo" intelectual, resgatando sua crítica da modernidade de um ponto de vista "marxista-libertário", por assim dizer, uma vez que ele acentua - para além dos "marxistas-weberianos" do passado - a centralidade da luta pela liberdade contra a subordinação da humanidade ao círculo vicioso do fetichismo da mercadoria, da racionalidade instrumental e do despotismo do Estado burocrático (as "cadeias de papel" de Kafka). Devido a essa perspectiva, que emerge de modo mais nítido após sua "redescoberta" de Walter Benjamin a partir do fim dos anos de 1970, Michael Löwy retoma a crítica marxista-weberiana como uma crítica da civilizaçáo capitalista moderna em seu conjunto, em um contexto marcado pela crise do modelo civilizatório estabelecido. Para Löwy, "mais do que nunca, e mais do que na época de Marx ou de Weber, nós estamos submetidos ao poder total de forças impessoais - o mercado, a finança, a dívida, o desemprego -, que se impóem aos indivíduos como um destino implacável" (p. 192).

Daí, igualmente, o caráter "romântico-revolucionário" da interpretação de Michael Löwy (cf. seu livro Revolta e melancolia: o romantismo na contramáo da modernidade, escrito em 1992 em conjunto com Robert Sayre - Löwy e Sayre, 1995) dessa crítica "marxista-weberiana-libertária" da modernidade. Em Löwy, tal perspectiva apresenta-se como uma crítica do mundo moderno "desencantado" e, táo importante quanto, das noçôes de "progresso" e de "dominação da natureza" - razão pela qual ela pode servir, na sua opiniāo, de ponto de partida para a construção de um ponto de vista "eco-socialista" contemporâneo. Esse "pessimismo revolucionário" - como diria Walter Benjamin em seu ensaio sobre os surrealistas - constitui a pedra angular das proposiçōes de Michael Löwy em torno da renovação contemporânea do marxismo, em oposição ao otimismo racionalista e hegeliano das versóes "à esquerda" das ideologias do progresso. Tal pessimismo constitui, em Löwy, o primeiro passo para a construção de uma "utopia concreta" (Ernst Bloch) futura, capaz de visualizar um mundo para além das ruínas do século XX. Não por acaso, o sociólogo franco-brasileiro se opóe fortemente às interpretaçôes marxistas "ortodoxas" da obra weberiana como aquela do Lukács da década de 1950, para quem Weber seria um dos múltiplos representantes do processo de "destruição da razão" característica da cultura alemão pré-nazista.

É bem verdade que, em muitos momentos, Michael Löwy - no afă de se contrapor a esse tipo de interpretaçáo - exagera no sentido contrário, com uma leitura excessivamente seletiva de Weber (e de outros autores), fazendo com que o sociólogo alemão pareça mais aquilo que ele, Löwy, gostaria que fosse do que o que ele efetivamente foi. Todavia, talvez seja o risco a correr quando se trata de uma interpretação cuja motivação subjacente é a tentativa de renovação substancial da análise "marxista-weberiana" do capitalismo contemporâneo. A originalidade da reflexão de Löwy - e do livro aqui resenhado - resulta exatamente da sua disposição a correr esse risco, sem medo da heresia. Sobre os escombros das ortodoxias e das polarizações ideológicas do século XX, Löwy entrevê a possibilidade de uma releitura criativa (embora polêmica) da obra dos dois pensadores alemães, amenizando suas diferenças a fim de destacar aquilo que os aproxima, na direção da reconfiguração de uma teoria social crítica para o século XXI.

\section{BIBLIOGRAFIA}

ADORNO, T. W. \& HORKHEIMER, M. ([1944] 1985), Dialética do esclarecimento. Tradução de Guido de Almeida. São Paulo, Zahar. BENJAMIN, W. ([1925] 2011), Origem do drama trágico alemão. Tradução de João Barrento. São Paulo, Autêntica.

. ([1929] 1994), "O surrealismo: o último instantâneo da inteligência europeia", in , Magia e técnica, arte e politica, tradução de Sérgio Paulo Rouanet, São Paulo, Brasiliense. 
HABERMAS, J. (2012), Teoria do agir comunicativo. Tradução de Paulo Astor Soethe e Flávio Beno Siebeneichler. São Paulo, Martins Fontes, 2 vols.

LÖWY, M. (1989), Redenção e utopia: o judaísmo libertário na Europa central. São Paulo, Companhia das Letras. . (2000), A guerra dos deuses: religião e politica na América Latina. Petrópolis, Vozes.

LÖWY, M. \& SAYRE, R. (1995), Revolta e melancolia: o romantismo na contramáo da modernidade. Petrópolis, Vozes.

LUKÁCS, G. ([1923] 2012), História e consciência de classe: estudos sobre a dialética marxista. Tradução de Rodnei Nascimento. São Paulo, Martins Fontes.

WEBER, M. ([1904-1905] 2004), A ética protestante e o espirito do capitalismo. Tradução de José Marcos Mariani Macedo. São Paulo, Companhia das Letras.

FABIO MASCARO QUERIDO é doutorando em sociologia pela Universidade Estadual de Campinas, com parte do doutoramento em realização na École de Hauts Études en Sciences Sociales, Paris, França. É bolsista da Fapesp. E-mail: fabiomascaro@yahoo.com.br. 